\title{
The Effect of Work Discipline, Spiritual Intelligence and Teamwork on Teacher Working Commitment in State Elementary School Subdistrict Selesai Of Langkat Regency
}

\author{
Christin Juli Emma P.A ${ }^{1)}$ Biner Ambarita ${ }^{2)}$, Benyamin Situmorang ${ }^{3)}$ \\ ${ }^{1)}$ Post-graduate student of UniversitasNegeri Medan ${ }^{2,3)}$ Lecturer of UniversitasNegeriMedan \\ Education Administration - UniversitasNegeri Medan \\ christinperanginangin22@gmail.com
}

\begin{abstract}
This study aims to determine the influence of work discipline on teacher teamwork, the influence of spiritual intelligence on the teamwork, the influence of work discipline on teacher work commitment and the influence of work discipline on teacher work commitment in State Elementary School SubdistrictSelesai of Langkat Regency. The research method used is quantitative method with path analysis model. The number of respondents as many as 143 people taken with Random Proportional Sampling. Research instrument in the form of questionnaire, is data analysis through path analysis and previously there is normality data test with kai square, linearity test and regression significance with Variance Analysis at significance level $\alpha$ equal to 0.05 . The results of this study were found there was a positive direct effect of work discipline on teamwork with path coefficient $\rho_{31}=0.327$, and the magnitude oftheeffectis $10.7 \%$; there is a direct influence of spiritual intelligence to teamwork with path coefficient $\rho_{32}$ of 0.256 and the magnitude oftheeffectis $6.2 \%$; there is a positive direct effect of work discipline on work commitment with path coefficient $\rho 41=$ 0.184 and the magnitude oftheeffectis $3.4 \%$; there is a positive direct effect of spiritual intelligence on work commitment with path coefficient $\rho 42=0.144$ and the magnitude oftheeffectis $2.1 \%$; there is a positive direct effect of teamwork on work commitment with path coefficient $\rho 43=0.235$ and the magnitude oftheeffectis $12.3 \%$. The higher the influence of work discipline, spiritual intelligence, and teamwork, the higher also in affecting the work commitment of teachers of State Elementary School SubdistrictSelesai of Langkat Regency.
\end{abstract}

Keywords: Work Discipline, Spiritual Intelligence, Teamwork, Working Commitment

\section{INTRODUCTION}

Walker in Ambarita (2014: 80) explained that "commitment is the willingness of people to stay with the organization and contribute energetically to achievement of share objectives", it can be explained that commitment is the willingness of people to stay with the organization and contribute passionately to achievement certain. Commitment can create someone determined to do something better than before ${ }^{[1]}$ Every teacher has certain reasons or motives in his commitment to his work. In general, some of the reasons or motives for committing the teacher to work found in school are that the teacher is committed because of the salary or income earned in accordance with what the teacher wants, the teacher is committed at school because he does not have another job choice, the teacher is committed to school because of his calling as a teacher. This is consistent with the aspects of commitment described by Colquit, Lepine and Wesson. Referring to the Teacher Competency Test results that have been won in 2015, the results show that the national average Teacher Competency Test is 53.02 for North Sumatra Province with an average value of 48.96 while the government targets an average score of 55. In addition, average average professional score is 54.77 while the average value of pedagogic competence is 48.94 .

The teacher competency test results in 2015 which managed to achieve the above scores were only seven provinces, namely: West Java, Central Java, Yogyakarta, DKI Jakarta, Bali, East Java, and Bangka Belitung. (source: sergur.kemendiknas.go.id accessed on May 13, 2016). ${ }^{[2]}$ Furthermore, based on the Ministry of National Education's Balitbang Data shows the percentage of teachers according to the feasibility of teaching in 2002-2003 in various education units as follows: for elementary schools that are worth teaching only $21.07 \%$ (state) and $28.94 \%$ (private); for SMP $54,12 \%$ (domestic) and $60.99 \%$ (private); for $65.29 \%$ SMA (state) and $58.26 \%$ (private). (source: https: //agus259.wordpress.com/pendidikan/). ${ }^{[3]}$

The teacher's work commitment to school organizations does not just happen, but has a fairly long and gradual process. According to Steers in Sopiah (2008: 163) the work commitment of teachers is determined by three factors that influence it, among others: (1) personal characteristics of performance, including his tenure in the school organization and variations in needs and desires that are different from each teacher, (2) characteristics of work, such as job identity and the opportunity to interact with fellow teachers, (3) work experience, such as reliability, (4) past organizations and the 
way other teachers express and talk about their feelings about school organizations. ${ }^{[4]}$

Winardi (2004: 73) explains that there are four factors that influence the work commitment of teachers in school organizations, namely: (1) Personal factors, such as age, gender, level of education, work experience, personality, etc., (2) Job characteristics for example, the scope of office, challenges in organizational work, organizational conflict, level of difficulty in work, etc., (3) Characteristics of structures, for example large / small school organizations, organizational forms such as centralization or decentralization, teacher union presence and level of control school organization is carried out against teachers. ${ }^{[5]}$

Rahmi (2017) The Effect Of Work Discipline Towards Organizational Commitment. In doing their task, a teacher should has a great work discipline. It assumes that in the process of teaching, a teacher should has some rules that must be followed and obeyed. ${ }^{[6]}$

Based on the opinions of some of these experts about factors that influence work commitment, there are several factors that researchers try to study, namely the factors of work discipline, spiritual intelligence and teamwork.

\section{METHODS}

This research was conducted on Public Elementary School teachers in Elementary School Subdistrict Selesai of Langkat Regency, North Sumatra Province, overall there were 37 schools. This research was conducted using quantitative methods. The model used is a path analysis model (path analysis). This study analyzes the influence of one variable on other variables, namely: (1) work discipline; (2) spiritual intelligence; (3) teamwork; (4) teacher work commitment. The data analysis technique used is infrential statistical techniques. Data collection techniques using primary data. Primary data is data obtained directly from the first source by distributing questionnaires or giving a number of statements to the respondent.

Validity (validity) test is used to determine the extent to which statement items function to capture data. To get the validity of the questionnaire, validity analysis was carried out. The instruments tested were analyzed using Product Moment correlation techniques. The instruments tested were analyzed using Product Moment correlation techniques with acceptance criteria:

a) if $r$ count $>r$ table then the item is valid, and

b) b) if $r$ count $<r$ table then the item is invalid at $\alpha=0.05$

Questionnaire reliability is determined using the Cronbach Alfa formula.

\section{DISCUSSION}

Description of the data for each research variable is presented in summary in the Summary table of the following Research Variable Data Description:
Table 4. 1. the frequency distribution and histogram of each research

\begin{tabular}{|c|c|c|c|c|}
\hline $\begin{array}{c}\text { Impormat } \\
\text { ion }\end{array}$ & $\mathrm{X}_{1}$ & $X_{2}$ & $X_{3}$ & $X_{4}$ \\
\hline Sampels & 143 & 143 & 143 & 143 \\
\hline Median & 88,10 & 87,13 & 85,83 & 84,85 \\
\hline Mode & 86,4 & 87,5 & 88,5 & 82,5 \\
\hline $\begin{array}{l}\text { Standard } \\
\text { deviation }\end{array}$ & 14,664 & $\begin{array}{r}16,27 \\
4 \\
\end{array}$ & 89,5 & $\begin{array}{r}16,06 \\
5 \\
\end{array}$ \\
\hline Variance & $\begin{array}{r}215,02 \\
4 \\
\end{array}$ & $\begin{array}{r}264,8 \\
48 \\
\end{array}$ & $\begin{array}{r}246,6 \\
52 \\
\end{array}$ & $\begin{array}{r}258,0 \\
89 \\
\end{array}$ \\
\hline Range & 65 & 65 & 63 & 63 \\
\hline $\begin{array}{l}\text { Minimum } \\
\text { Score }\end{array}$ & 50 & 54 & 53 & 53 \\
\hline $\begin{array}{l}\text { Maksimu } \\
\text { m Score }\end{array}$ & 115 & 119 & 116 & 116 \\
\hline $\begin{array}{l}\text { Score } \\
\text { total of }\end{array}$ & 12599 & 12460 & 12273 & 12133 \\
\hline $\begin{array}{l}\text { Ideal } \\
\text { Maximum } \\
\text { Score } \\
\end{array}$ & 115 & 135 & 140 & 140 \\
\hline $\begin{array}{l}\text { Ideal } \\
\text { Minimum } \\
\text { Score } \\
\end{array}$ & 23 & 27 & 28 & 28 \\
\hline $\begin{array}{l}\text { Ideal } \\
\text { average } \\
\text { score } \\
\end{array}$ & 69 & 81 & 84 & 84 \\
\hline $\begin{array}{l}\text { Ideal } \\
\text { Standard } \\
\text { deviation }\end{array}$ & 15,33 & 18 & 18,67 & 18,67 \\
\hline
\end{tabular}

Information :

$\mathrm{X} 1=$ work discipline $\mathrm{X} 2=$ spiritual intelligence

$\mathrm{X} 3=$ teamwork $\mathrm{X} 4=$ work commitment

Furthermore, the frequency distribution and histogram of each research variable are presented.

\section{Work discipline}

Frequency distribution of variable variables of work discipline can be seen in the following table. 
Table 4. 2. Distribution of Frequency of Work Discipline

\begin{tabular}{|l|l|l|l|l|}
\hline Class & $\begin{array}{l}\text { Interval } \\
\text { Class }\end{array}$ & $\begin{array}{l}\text { Absolute } \\
\text { Frequency }\end{array}$ & $\begin{array}{l}\text { FrequencyRelatif } \\
(\%)\end{array}$ & $\begin{array}{l}\text { Frequency } \\
\text { Kumulatif (\%) }\end{array}$ \\
\hline 1 & $50-58$ & 7 & 4,90 & 7,00 \\
\hline 2 & $59-67$ & 10 & 6,99 & 10,00 \\
\hline 3 & $68-76$ & 16 & 11,19 & 16,00 \\
\hline 4 & $77-85$ & 34 & 23,78 & 34,00 \\
\hline 5 & $86-94$ & 41 & 28,67 & 41,00 \\
\hline 6 & $95-103$ & 17 & 11,89 & 17,00 \\
\hline 7 & $104-112$ & 11 & 7,69 & 11,00 \\
\hline 8 & $113-121$ & 7 & 4,90 & 7,00 \\
\hline Total & & 143 & 100,00 & 143,00 \\
\hline & & & & \\
\hline
\end{tabular}

Based on the data in Table 4.1. and Table 4.2. above can be seen that the highest score is 115 , the lowest score is 50, and the standard deviation is 14.664 while the ideal highest score is 115 , the lowest lowest score is 23 , and the average ideal score is 69 and the ideal standard deviation is 15.33 . The frequency distribution of work discipline scores is shown in the histogram as in Figure 4. 1. below:

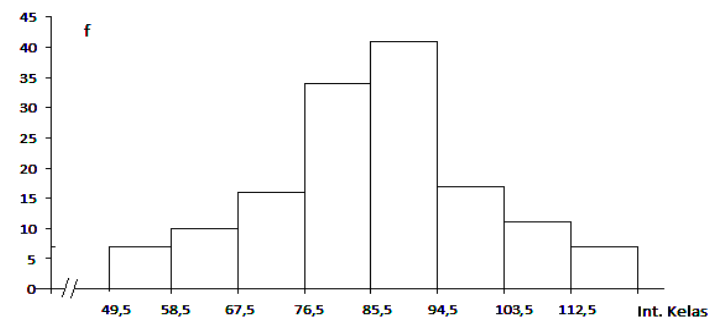

Figure 4. 1. Histogram of work discipline score

2. Spiritual intelligence

Frequency distribution of spiritual intelligence variable scores can be seen in the following table.

Table 4. 3. Frequency Distribution of Spiritual Intelligence Scores

\begin{tabular}{|l|l|l|l|l|}
\hline Class & $\begin{array}{l}\text { Interval } \\
\text { Class }\end{array}$ & $\begin{array}{l}\text { Absolute } \\
\text { Frequency }\end{array}$ & $\begin{array}{l}\text { Frequency } \\
\text { Relatif }(\%)\end{array}$ & $\begin{array}{l}\text { Frequency } \\
\text { Kumulatif } \\
(\%)\end{array}$ \\
\hline 1 & $54-62$ & 9 & 6,29 & 9,00 \\
\hline 2 & $63-71$ & 15 & 10,49 & 15,00 \\
\hline 3 & $72-80$ & 19 & 13,29 & 19,00 \\
\hline 4 & $81-89$ & 33 & 23,08 & 33,00 \\
\hline 5 & $90-98$ & 26 & 18,18 & 26,00 \\
\hline 6 & $99-107$ & 21 & 14,69 & 21,00 \\
\hline 7 & $108-116$ & 13 & 9,09 & 13,00 \\
\hline 8 & $110-117$ & 7 & 4,90 & 7,00 \\
\hline Total & & 143 & 100,00 & 143,00 \\
\hline
\end{tabular}

Based on the data in Table 4.1. and Table 4.3. above can be seen that the highest score is 119 , the lowest score is 54, and the standard deviation is 16,274 while the ideal highest score is 1135 , the ideal lowest score is 27 , and the average ideal score is 81 and the ideal standard deviation is 18 . Frequency distribution of intelligence scores spiritual is shown in the histogram as in Figure 4.2:

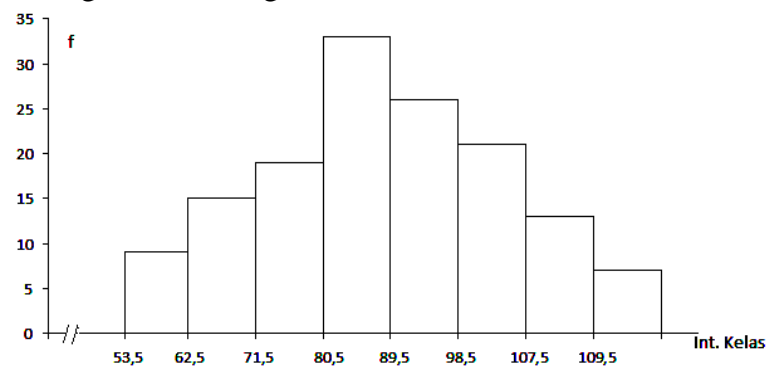

Figure 4. 2. Histogram of Spiritual Intelligence Score

3. Teamwork

The frequency distribution of teamwork variable score can be seen in the following table.

Table 4. 4. Teamwork Score Frequency Distribution

\begin{tabular}{|l|l|l|l|l|}
\hline Class & $\begin{array}{l}\text { Interval } \\
\text { Class }\end{array}$ & $\begin{array}{l}\text { Absolute } \\
\text { Frequency }\end{array}$ & $\begin{array}{l}\text { Frequency } \\
\text { Relatively } \\
(\%)\end{array}$ & $\begin{array}{l}\text { Frequency } \\
\text { Kumulatif } \\
(\%)\end{array}$ \\
\hline 1 & $53-60$ & 10 & 10,00 & 10,00 \\
\hline 2 & $61-68$ & 13 & 13,00 & 13,00 \\
\hline 3 & $69-76$ & 14 & 14,00 & 14,00 \\
\hline 4 & $77-84$ & 27 & 27,00 & 27,00 \\
\hline 5 & $85-92$ & 28 & 28,00 & 28,00 \\
\hline 6 & $93-100$ & 27 & 27,00 & 27,00 \\
\hline 7 & $101-108$ & 14 & 14,00 & 14,00 \\
\hline 8 & $109-116$ & 10 & 10,00 & 10,00 \\
\hline Total & & 143 & 143,00 & 143,00 \\
\hline
\end{tabular}

Based on the data in Table 4.1. and Table 4.4. above can be seen that the highest score is 116 , the lowest score is 53 and the standard deviation is 15.705 while the ideal highest score is 140 , the lowest lowest score is 28 , and the average ideal score is 84 and the ideal standard deviation is 18.67 . The frequency distribution of teamwork scores is shown in the histogram as in Figure 4. 3. below.

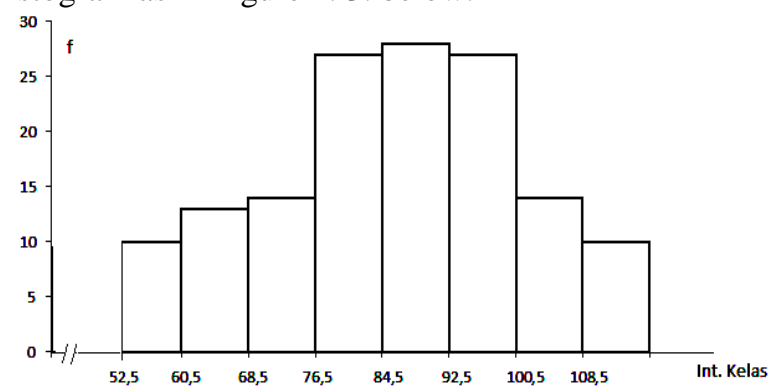

Figure 4. 3. Teamwork Score Histogram 


\section{Teacher's work commitment}

The frequency distribution of teacher work commitment variables can be seen in the following table.

Table 4.5 The frequency distribution of teacher work commitment

\begin{tabular}{|l|l|l|l|l|}
\hline Class & $\begin{array}{l}\text { Interval } \\
\text { Class }\end{array}$ & $\begin{array}{l}\text { Absolute } \\
\text { Frequency }\end{array}$ & $\begin{array}{l}\text { Frequency } \\
\text { Relatively } \\
(\%)\end{array}$ & $\begin{array}{l}\text { Frequency } \\
\text { Kumulatif } \\
(\%)\end{array}$ \\
\hline 1 & $53-60$ & 10 & 10,00 & 10,00 \\
\hline 2 & $61-68$ & 14 & 14,00 & 14,00 \\
\hline 3 & $69-76$ & 15 & 15,00 & 15,00 \\
\hline 4 & $77-84$ & 33 & 33,00 & 33,00 \\
\hline 5 & $85-92$ & 27 & 27,00 & 27,00 \\
\hline 6 & $93-100$ & 20 & 20,00 & 20,00 \\
\hline 7 & $101-108$ & 14 & 14,00 & 14,00 \\
\hline 8 & $109-116$ & 10 & 10,00 & 10,00 \\
\hline Jumlah & & 143 & 143,00 & 143,00 \\
\hline
\end{tabular}

Based on the data in Table 4.1. and Table 4.5. above can be seen that the highest score is 116, the lowest score is 53, and the standard deviation is 16.065 while the ideal highest score is 140 , the lowest lowest score is 28 , and the average ideal score is 84 and the ideal standard deviation is 18.67 . The frequency distribution of teacher work commitment scores is shown in the histogram as in Figure 4.4 below:

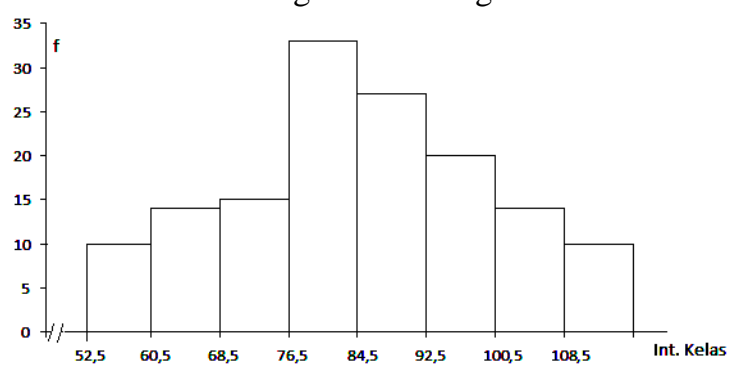

Figure 4. 4.Histogram Score Teacher Work Commitment

In accordance with the theoretical model developed in this study, there are six hypotheses tested by Path Analysis. Based on the results of the test obtained a path diagram that describes the structure of the causal relationship between exogenous variables with endogenous variables as in Figure 4.5. following.

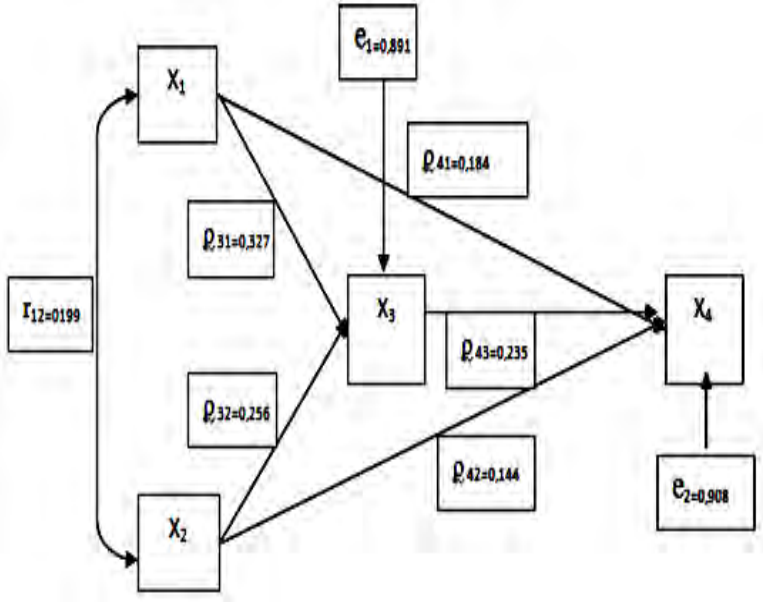

Figure 4. 5. Pathway of Research Variable Hypothesis Testing Path Diagram

Description: $\mathrm{X} 1$ = work discipline

$$
\begin{aligned}
& \mathrm{X} 2=\text { spiritual intelligence } \\
& \mathrm{X} 3=\text { teamwork } \\
& \mathrm{X} 4=\text { work commitment }
\end{aligned}
$$

$1,2,3=$ the residual variable

\section{CONCLUSION}

Based on the result of the study and analysis had been done, so it can gain some conclusion as follows:

1. Work discipline has a direct positive effect on the teamwork of teachers in public elementary schools in State Elementary School Subdistrict Selesai of Langkat Regency. In other words, the better the communication of work discipline, the stronger the teamwork of teachers in State Elementary School Subdistrict Selesai of Langkat Regency.

2. Spiritual intelligence has a direct positive effect on the teamwork of public elementary school teachers in State Elementary School Subdistrict Selesai of Langkat Regency. In other words, the stronger spiritual intelligence, the higher the teamwork in State Elementary School Subdistrict Selesai of Langkat Regency.

3. Work discipline has a direct positive effect on the work commitment of teachers in public elementary schools in State Elementary School Subdistrict Selesai of Langkat Regency. In other words, the better the work discipline, the stronger the work commitment of teachers in State Elementary School Subdistrict Selesai of Langkat Regency.

4. Spiritual intelligence has a direct positive effect on the work commitment of teachers in State Elementary School Subdistrict Selesai of Langkat Regency. In other words, the stronger the spiritual intelligence, the stronger the work commitment of teachers in State Elementary School Subdistrict Selesai of Langkat Regency. 
5. Teamwork has a direct positive effect on the work commitment of teachers in public elementary schools in State Elementary School Subdistrict Selesai of Langkat Regency. In other words, the higher the teamwork, the stronger the teacher's work commitment in State Elementary School Subdistrict Selesai of Langkat Regency.

\section{SUGGESTIONS}

1. Implications for the Education Office

The research findings show that work discipline, job satisfaction, teamwork influence the work commitment of teachers in Langkat Regency. This means that the work commitment of teachers in Langkat Regency can increase if work discipline, job satisfaction, teamwork are improved. For this reason, the Head of the Langkat Regency Education Office can encourage and provide financial support activities that socialize the importance of work discipline, job satisfaction, teamwork in order to increase teacher work commitment in Langkat Regency.

2. Implications for Headmaster

In connection with research findings that show that work discipline, job satisfaction, teamwork influence the work commitment of teachers in Langkat Regency. The principal can make efforts that can improve the work commitment of the teacher effectively and efficiently as follows:

a. Fostering and guiding teachers about the importance of work commitment in an institution in order to realize the goals of educational institutions.

b. Providing opportunities for teachers to apply innovative ideas and apply them through conducting action research to improve the quality of learning.

3. Implications for Teachers

In connection with research findings that show that work discipline, job satisfaction, teamwork influence the work commitment of teachers in Langkat Regency. Therefore the teacher can make an effort that can realize the teacher's work commitment which is expected to be effective and efficient as follows:

a. Follow education and training activities in the field of work discipline, job satisfaction, teamwork, and teacher work commitments.

b. Cooperating with school principals, teachers, students and other stakeholders to improve work discipline, job satisfaction, teamwork, and teacher work commitments.

4. The findings of this study indicate that work discipline, job satisfaction, teamwork influence the work commitment of teachers. This means enriching the nature of education management where to increase teacher work commitment can be done through work discipline, spiritual intelligence, elementary school teamwork.

\section{REFERENCES}

[1] Ambarita 2014. Perilaku Organisasi. Bandung: Alfabeta

[2] Sergur.kemendiknas.go.id accessed on May 13, 2016.

[3] https:agus259.wordpress.com/pendidikan/

[4] Sopiah. 2008. PerilakuOrganisasi. Yogyakarta: Andi

[5] Winardi, 2004. Manajemen Perilaku Organisasi, Edisi Revisi Cetakan Pertama, Prenada Media, Jakarta.

[6] Rahmi F.S, Tiur A.S \&YasaratodoWau: The Effect Of Work Discipline, Job Satisfaction And Work Motivation Towards Teacher Organizational Commitment In SmpNegeri Of Medan Kota District. IOSR Journal of Research \& Method in Education (IOSR-JRME), Vol. 7 